\title{
A gyermekkori diabetes sajátosságai a különböző életszakaszok tükrében
}

\author{
Körner Anna dr.
}

\begin{abstract}
Osszefoglalas
A szerzö röviden ismerteti a gyermekkorban elöforduló különbözö diabetesformákat, a gyermekkorban leggyakrabban diagnosztizált 1-es típusú diabetes mellett a 2-es típusú diabetest, a monogénes diabetesformákat, a poszttranszplantációs diabetest és a cystás fibrosishoz társuló diabetest. Az egyes életszakaszok jellegzetes sajátságainak tükrében irja le azokat a speciális problémákat, amelyek az adott életkorra jellemzök. Kiemelten foglalkozik a csecsemök és kisdedek, valamint a serdülök diabetes-menedzselési kérdéseivel.
\end{abstract}
Kulcsszavak: 1-es típusú diabetes, 2-es típusú diabetes, monogénes diabetesformák, poszttranszplantációs diabetes, cystás fibrózishoz társuló diabetes

\section{Special features of childhood diabetes in the light of different age groups}

Summary: The author briefly describes the different types of diabetes occurring in childhood; beside the most prevalent type 1 diabetes, type 2 diabetes, monogenic diabetes, posttransplantation diabetes and cystic fibrosis related diabetes. In the light of the characteristic features in the different age groups, the author expounds special problems related to the given age. She is focusing on the management of diabetes occurring in infants and toddlers, as well as in puberty.

\begin{abstract}
Key words: type 1 diabetes, type 2 diabetes, monogenic diabetes, posttransplantation diabetes, cystic
\end{abstract} fibrosis related diabetes

\section{Rövidítések}

MODY: felnőttkori típusú diabetes fiataloknál (maturity onset diabetes in the young); NODAT: transzplantáció után kialakuló friss diabetes (new onset diabetes after transplantation); OGTT: orális glukóztolerancia-teszt (oral glucose tolerance test); PNDM: permanens neonatális diabetes (permanent neonatal diabetes); T1DM: 1-es típusú diabetes (type 1 diabetes); T2DM: 2-es típusú diabetes (type 2 diabetes); TNDM: átmeneti újszülöttkori diabetes (transient neonatal diabetes)

A diabetes a gyermekkor egyik leggyakoribb krónikus megbetegedése. Az Amerikai Egyesült Államokban kb. 200000, 20 évnél fiatalabb diabeteses beteg él. ${ }^{1}$ A ,SEARCH for Diabetes in Youth" (SEARCH) vizsgálat közelmúltbeli jelentése alapján jelenleg 1000, 20 évnél fiatalabb lakosra 1,93 frissen diagnosztizált diabeteses beteg jut, ami 2001 és 2009 között 21\%-os növekedést jelent az előfordulásban. ${ }^{2}$ Ezek a statisztikai adatok híven mutatják a gyermekkori diabetes prevalenciájának látványos nö- vekedését, és ez a szakemberekre fokozott felelősséget ró.

Néhány évtizeddel ezelőtt a gyermekkori diabetes palettája meglehetősen egyszínű volt; az 1-es típusú diabetes (T1DM) mellett gyermekkorban nemigen tudtunk egyéb diabetesformát diagnosztizálni. Mostanra azonban a paletta jelentősen kiszínesedett. Bár napjaikban is a gyermekkorban diagnosztizált diabeteses esetek több mint $85 \%$ a 1-es típusú, a fiatalkorban diagnosztizált 2-es típusú diabetes (T2DM) előfordulása is emelkedő 
tendenciát mutat. Ez elsősorban a gyermekkori elhízás egyre szélesebb körű elterjedésével hozható összefüggésbe. Gyermekkorban a T2DM hosszú ideig rejtve maradhat, ami elsősorban azon alapszik, hogy gyermekkorban a betegség sok esetben tünetmentes vagy csak enyhe tünetekkel jár. A diagnózis felállításához a rizikópopulációban (kövér gyermekek, olyan gyermekek, akiknek első fokú rokonai között a T2DM halmozottan fordul elö, valamint azok a gyerekek, akik az inzulinrezisztencia fenotipikus jegyeit, pl. az acanthosis nigricanst viselik magukon) orális glukóztolerancia-teszt (OGTT) elvégzésére van szükség., ${ }^{3,4}$ A gyermekkori 1-es és 2-es diabetes elkülönítése nem mindig egyszerü. Ebben a korcsoportban előfordulhat, hogy az egyik típusra jellemző tünet a másik típusban is fellelhető. Az obesitas prevalenciájának rohamos növekedése mellett előfordulhat például, hogy a T1DM egy eleve elhízott gyermekben alakul ki, illetve T2DM-ben sem kizárt a ketoacidosis fellépése. Kiemelendő, hogy a fiatalkorban diagnosztizált T2DM szövődmények szempontjából sokkal agresszívebb, mint a későbbi életkorban diagnosztizált betegség. ${ }^{5}$

A diagnosztikus arzenál bővülése (autoantitestek meghatározása, molekuláris genetikai vizsgálatok elterjedése) napjainkban már lehetővé teszi a monogénes diabetesformák (maturity onset diabetes in the young - MODY) kórismézését. A monogénes diabetesformák az összes diabeteses eset 1-2\%-át teszik ki, autoszomális domináns öröklésmenetet mutatnak. Leginkább a T2DM-hez hasonlítanak, de jellemzően 25 éves kor előtt manifesztálódnak. Napjainkban már 11 olyan gén ismert, amelyek mutációja MODY kialakulásához vezet. Felismerésük a megfelelő kezelési mód kiválasztása szempontjából alapvető fontosságú. ${ }^{6}$

A szolid szervtranszplantációk számának növekedése a poszttranszplantációs diabetes egyre gyakoribb megjelenéséhez vezet. ${ }^{7}$ A betegség a transzplantációban részesülő betegek 2-50\%-át érinti. Ellátásuk jelentős anyagi ráfordítással jár, fellépésük növeli a graftelégtelenséget, cardiovascularis szövődményekhez és halálhoz vezethet. A jelentős eltérés, amelyet a poszttranszplantációs diabetes (new onset diabetes after transplantation - NODAT) prevalenciájában észlelnek, a betegség különböző definíciójában rejlik. Egyesek az emelkedett éhomi vércukrot, mások a kóros OGTT eredményét, illetve az emelkedett $\mathrm{HbA}_{1 c}$-értéket tekintik a diagnózis feltételének. ${ }^{8,9}$ Számos módosítható, illetve nem módosítható kockázati tényezőt azonosítottak a NODAT kialakulása szempontjából. A módosítható tényezők közé tartozik az obesitas és az immunszuppresszív terápia megválasztása. ${ }^{10} \mathrm{~A}$ tacrolimus-alapú immunszuppreszszív kezelés például növeli a NODAT kockázatát a ciklosprin-alapú terápiával összehasonlítva. A nem módosítható kockázati tényezők közé tartozik a diabetesre nézve pozitív családi anamnézis, a polycystás vesebetegség, a hepatitis $\mathrm{C}$ fertőzés, a női nem és a beteg idősebb életkora. ${ }^{11} \mathrm{~A}$ szolid szervtranszplantáció utáni diabetes kialakulásában megkülönböztetett helyet foglal el a tüdőtranszplantáció. Gyermekkorban a tüdőtranszplantáció leggyakoribb oka a cystás fibrosis, amely sokszor már a tüdőtranszplantáció előtt is a szénhidrátanyagcsere-zavar megjelenésével jár. Cystás fibrosisban ugyanis nemcsak a pancreas emésztőenzim-termelése károsodik, hanem annak endokrin funkciója is. A betegségre jellemző szövetpusztulás zavart okoz az inzulintermelésben, ami csökkent glukóztoleranciához, idővel diabetes kialakulásához vezet. Cystás fibrosisban az életkor előrehaladtával párhuzamosan a diabetes prevalenciája nő. Míg az adoleszcens betegek kb. 19\%-a szenved cukorbetegségben, addig a húszas éveiben járó betegek 40\%-ánál, a 30-39 évesek 50\%-ánál, a 40 év felettiek $52 \%$-ánál alakul ki diabetes. ${ }^{12}$ Mindezek alapján a nemzetközi ajánlások szerint a cystás fibrosisban szenvedő betegeket 10 éves kortól rendszeresen kell szűrni diabetes irányába OGTT segítségével. A hyperglykaemia manifesztálódásakor az inzulinkezelést mihamarabb el kell kezdeni. ${ }^{13}$

A gyermekek, legfőképpen a kisgyermekek diabetesének menedzselését hosszú éveken keresztül a hypoglykaemiától való félelem határozta meg. Éppen ezért egészen a közelmúltig gyermekekben a felnőttekhez képest magasabb $\mathrm{HbA}_{1 \mathrm{c}}$-céltartományokat határoztak meg: óvodásokban $<8,5 \%$, iskolásokban $<8,0 \%$ volt a megfelelőnek tartott $\mathrm{HbA}_{1 \mathrm{c}}$-tartomány, és csak a serdülők esetében fogadták el a $<7,5 \%$-os célértéket. ${ }^{14} \mathrm{Az}$ európaiak már korábban, az amerikaiak csak az elmúlt évben deklarálták, hogy - bár a célértéket individuálisan kell meghatározni - a gyerekek számára is a 7,5\% alatti $\mathrm{HbA}_{1 \mathrm{c}}$ a kívánatos. ${ }^{15}$ Ugyan sok vita 
előzte meg a jelenlegi állásfoglalást, de ma már elfogadott az a nézet, hogy a késői szövődmények megjelenésének idejére a prepubertális évek is hatással vannak. ${ }^{16}$

$\mathrm{Az}$ ember egész élete során változik. Az a robbanásszerű átalakulás azonban, ami az élet első két évtizedében történik, amelynek során a 3 kg-os, 50 cm hosszú újszülöttből egy $70 \mathrm{~kg}$-os $180 \mathrm{~cm}$ magas felnőtt lesz, az élet egyetlen későbbi szakaszában sem jön létre. Nem meglepő tehát, hogy a diabetes jellemzői is hatalmas változáson mennek keresztül az élet első 18-20 évében.

\section{Neonatális diabetes}

A Rousseau-tól eredeztetett mondás, azaz, hogy „a gyerek nem kicsinyített felnőtt”, igaz a gyerekkori diabetesre is, amely élesen elkülönül a betegség felnőttkorban megjelenő formájától.

Hatványozottan igaz ez az - általában 6 hónapos kor előtt fellépő - neonatális diabetesre, amely ugyan rendszerint inzulinnal kezelendő, de etiopatogenezise egészen más, mint a gyermekkor későbbi szakaszaiban megjelenő 1-es típusú diabetesé. A betegségnek tranziens (TNDM) és permanens (PNDM) formája ismert, előfordulási gyakoriságuk 1:300 000-400000. Sem az etiopatogenezis, sem a klinikai kép szempontjából nem mutatnak hasonlóságot a gyermekkori T1DM-mel, illetve a két kórkép egyike sem homogén a kóreredet szempontjából. A TNDM főleg éretlen újszülöttekben jelentkezik az első élethetekben, gyakran macroglossia, craniofacialis anomáliák kíséretében. A betegség hátterében genetikai eltérés (a 6 . kromoszóma uniparentális diszómiája) áll. Ezekben a betegekben általában pár hónapos korra a diabetes elmúlik, de a későbbiekben - általában a pubertás idején - gyakran alakul ki 2-es típusú diabetes. ${ }^{17,18}$ A PNDM-es betegek jelentős részében a betegség létrejöttét olyan gének mutációja okozza, amelyek a béta-sejt fejlődésében, illetve funkciójában játszanak szerepet. Számos esetben a glukokináz enzim hiánya, a pancreas béta-sejtjei ATP-függő K-csatornáinak vagy az inzulin génrégiónak a mutációja igazolható. Esetenként pancreas-agenesia áll a háttérben. ${ }^{19,20} \mathrm{Az}$ egyre szélesebb körben, most már hazánkban is elérhető genetikai vizsgálat segíthet az adekvát kezelési stratégia megválasztásában; speciális esetekben, amikor a betegséget az ATP-szenzitív káliumcsatorna alegységeit kódoló gének (KCNJ11 vagy $\mathrm{ABCC} 8)$ mutációja okozza, az állapot nagy dózisú sulfanylureával kezelhető.

\section{A csecsemö- és kisdedkorban fellépö diabetes}

A T1DM előfordulása az elmúlt évtizedben az egész gyermekpopulációban markáns növekedést mutat, ${ }^{21}$ ugyanakkor az incidencia emelkedése az 5 évesnél fiatalabb gyermekeket aránytalanul nagyobb mértékben sújtja. Hogy mit jelent egy csecsemő vagy kisded diabetesének sikeres menedzselése, azt csak az érzi át igazán, aki ezzel a problémával nap mint nap megküzd. A kicsik kiszámíthatatlan fizikai aktivitása, szertelen étkezési szokásai hatalmas feladat elé állítja a szülőket. Egy jól működő, orvost, edukátort, dietetikust, szociális munkást és pszichológust magában foglaló diabetesellátó csapat sokat tud ebben segíteni, de a harcot a mindennapok szintjén elsősorban a család vívja meg. A kisgyerekek éppen az említett okok miatt (hatalmas ingadozások a fizikai aktivitásban és a táplálékfelvételben) különösen hajlamosak a hypoglykaemiára, ami egyrészt drámai félelmet okoz a szülőkben, másrészt a gyermek kognitív károsodásához vezet. Az utóbbi évek kutatásai azt is igazolták, hogy nemcsak a hypoglykaemia, de a hyperglykaemia is károsítja a fejlődő agyat. ${ }^{22}$ Tovább súlyosbítja a helyzetet, hogy az egészen fiatal korosztályban nemcsak a diagnóziskor észlelt klinikai tünetek mások, mint az idősebb gyermekekben, de a kórosan alacsony vércukorszint sem a nagyobb gyermekekben, illetve a felnőtteknél megszokott módon jelentkezik. ${ }^{23} \mathrm{Az}$ is bonyolítja a képet, hogy a csecsemők és kisdedek nem képesek a hypoglykaemia érzetét kommunikálni, ami azt eredményezi, hogy a kisgyerekek szülei naponta akár 10-15 alkalommal is megmérik gyermekük vércukorszintjét. Az egészen fiatal gyermekek kezelésében áttörést jelent az inzulinpumpa-kezelés, amellyel az inzulin dozírozásának korábban soha nem tapasztalt finomhangolása (akár 0,025 E/órás bazális inzulinváltoztatás lehetősége) valósítható meg. A hypoglykaemia kivédésében hatalmas áttörést jelent a szenzoraugmentált inzulinpumpák megjelenése, 
amelyek nem csupán percről percre mutatják az aktuális cukorszintet és a cukorszint változásának irányát, hanem - legmodernebb változataik - arra is képesek, hogy hypoglykaemia esetén (vagy amikor a cukorszint az elkövetkező 30 percen belül megjósolhatóan el fogja érni a hypoglykaemia beállított küszöbértékét) az inzulinadagolást átmenetileg felfüggessze. Ezzel egyrészt hatalmas biztonságot nyújt a betegek számára, másrészt oldja azt a feszültséget, amit a kis diabeteses gyermeket nevelő családok napi szinten megélnek. ${ }^{24}$

Diabetesszel vagy anélkül, a kisiskoláskor egy viszonylag nyugalmas életszakasz. A gyermekek már képesek a gyakorlati és - szükség szerint - az elméleti ismeretek elsajátítására. Igyekvőek, nagy bennük a megfelelési vágy. Jól tükröződik ez a diabetesszel kapcsolatos tevékenységükben is. Hihetetlen ügyességgel sajátítják el a vércukormérés és inzulinadás fortélyait, betartják a szabályokat. Ebben az életkorban kivételes, ha a gyerek anyagcserekontrolljának minősége nem megfelelő.

A néhány viszonylag könnyen menedzselhető év után jön a serdülőkor, amikor minden az anyagcsere-egyensúly megbillenésének irányába hat. A testméretekben bekövetkező rapid változások, de még inkább az inzulinrezisztenciát előidéző hormonális tevékenység sokszor drámai romlást eredményez az anyagcserekontroll minőségében. Az élettani hatások mellett ebben kulcsszerepet játszanak a serdülőkort kísérő pszichés változások is. Elkezdődik a lázadás kora. A gyerek, hogy megvalósítsa felnőtt önmagát, mindent és mindenkit megkérdőjelez. Hatványozottan érvényes ez a diabetesszel kapcsolatos előírásokra. A szülők nagytakarításkor megtalálják a hegyekben felhalmozott csokipapírokat. Sokszor a szülő csak az ellenőrzések alkalmával szembesül a ténnyel, hogy gyermeke alig méri a vércukrát, a napló üres, vagy olyan értékek szerepelnek benne, amelyek „köszönő viszonyban” sincsenek a vércukormérő memóriájában szereplő értékekkel. A szülő kétségbeesik, hogyan lett az ő ragaszkodó, szófogadó kisfiából-kislányából ilyen ellenséges, kezelhetetlen ,szörnyeteg”. Sok szülő úgy gondolja, hogy ha a diabetes egészen fiatal korban kezdődött, azaz a gyereknek már emlékképe sincsen arról, hogy milyen volt diabetes nélkül élni, ez megkíméli őket a kamaszkori éles szembefordulásoktól. Ez azonban korántsem így van. Néha ezekben az esetek- ben a legerőteljesebb a lázadás, hiszen ilyenkor döbbennek rá, hogy mit jelent számukra diabeteszszel élni. A kisgyerekek gyakran büszkén mutatják környezetüknek a diabetes menedzseléséhez szükséges penjeiket, pumpájukat, vércukormérőjüket, kamaszkorban azonban igyekeznek elrejteni mindent, ami a diabetesszel kapcsolatos. Szégyellik betegségüket, nem akarnak különbözni társaiktól. Ezért aztán gyakran inkább kihagyják pl. a déli, az iskolában beadandó inzulinadagot. Az elfelejtett bólus (akár inzulinpumpában, akár hagyományos intenzív inzulinkezelésen) a kamaszkorban meredeken felfelé ívelő $\mathrm{HbA}_{1 c}$-érték egyik legmeghatározóbb tényezője. ${ }^{25,26} \mathrm{Az}$ inzulinkihagyás miatt szinte állandóan hyperglykaemiában (sok esetben acetonaemiával) egyensúlyozó kamasznak olykor elég egy enyhe megfázás, ami a metabolikus stressz állapotot előidézve a diabeteses ketoacidosisba taszítja a gyermeket. Serdülőkorban éppen ezért nem ritka a diabeteses ketoacidosis, számos esetben ismétlődő jelleggel is. Sajnos - bár a kamaszok azok, akik számára a flexibilisebb életmódot kínáló inzulinpumpa-kezelés az egészen fiatalok mellett a leginkább segítséget nyújthatna -, serdülőkorban gyakran hiányoznak a sikeres inzulinpumpa-kezelés minimumfeltételei. Hiába van meg az indikáció (magas $\mathrm{HbA}_{1 \mathrm{c}}$, hajnali jelenség stb.), a hiányzó vércukormérés, a kihagyott bólusok, a szénhidrátszámolás elhagyása, a nem megfelelő időközben történt szerelékcsere sokszor veszélyesebb helyzetekbe sodorja az inzulinpumpát használó adoleszcenst, mint a hagyományos penes kezelés. A serdülőket sokszor drámai helyzetbe taszítja a veszélyérzet hiánya, ami az alkoholfogyasztásban, súlyosabb esetben a droghasználatban is megnyilvánul.

A diabeteshez gyakran társulnak pszichés zavarok, amelyek közül a leggyakoribb a depresszió, a szorongás és az evészavarok. Az 1-es típusú diabeteses serdülőkben - elsősorban a lányokban nagy az evészavarok fellépésének kockázata. A klasszikus kórképek (anorexia, bulimia) mellett az evészavar „enyhébb formái” különösen gyakoriak kamaszkorban. A serdülő lányok rettegnek az elhízástól, így gyakran alkalmazzák az inzulinkihagyást mint „testsúlyszabályozó” eszközt. Ez azonban lehetetlenné teszi a jó anyagcsere-állapot kialakulását, és a gyermeket gyakran az anyagcsere-felborulás veszélyébe sodorja. ${ }^{27}$ 
Az utóbbi évek vizsgálatai kimutatták, hogy az emberi agy fejlődése csak kb. 24 éves korra fejeződik be. A serdülők agyműködését vizsgáló kutatók azt találták, hogy ebben az életkorban olyan átrendeződés megy végbe az agyban, ami felelős lehet a túlzott kockázatvállalásért, újfajta, sokszor veszélyes élmények kereséséért vagy éppen a megdöbbentő válaszreakciókért. Egyre több bizonyíték van arra nézve, hogy a kockázatkereső magatartás mintegy bele van programozva a serdülők agyába. Agyunknak van egy nagyon izgalmas területe: a limbikus rendszer. Ez a terület felelős a jutalomérzet kialakításáért, nem meglepő, hogy a kockázatvállalás éppen ezt a területet hozza működésbe. Kockázatosan viselkedni izgalmas, érdekes. A kutatások szerint a limbikus rendszer serdülőkorban rendkívül érzékeny, ezzel szemben az elülső homloklebeny - amely megakadályozza, hogy túlságosan sokat kockáztassunk - ebben az időszakban még fejlődésben van. ${ }^{28}$

A hazai gyakorlat szerint - bár ebben kisebb-nagyobb eltérés van az egyes centrumok között - a diabeteses gyermeket általában a középiskolai tanulmányok befejezésekor, a „készülődő felnőttség” (,emerging adulthood”) idején adjuk át a felnőttgondozásnak. A hazai gyermek- és felnőttdiabetológusok ugyan hagyományosan jó és szoros kapcsolatot ápolnak, még így is elő-előfordul, hogy a betegek az átadás során „elkallódnak". Ezért célunk, hogy a gyermekgondozásból a felnőttgondozásba történő átvezetés folyamatát nemzetközi példákra is támaszkodva ${ }^{29}$ minél zökkenőmentesebbé tegyük.

\section{Irodalom}

1. Pettitt DJ, Talton J, Dabelea D, Divers J, Imperatore G, Lawrence JM, et al.; SEARCH for Diabetes in Youth Study Group: Prevalence of diabetes in U.S. youth in 2009: the SEARCH for diabetes in youth study. Diabetes Care 2014; 37: 402-408. doi:10.2337/dc13-1838

2. Dabelea D, Mayer-Davis EJ, Saydah S, Imperatore G, Linder B, Divers J, et al., SEARCH for Diabetes in Youth Study: Prevalence of type 1 and type 2 diabetes among children and adolescents from 2001 to 2009. JAMA 2014; 311: 1778-1786. doi:10.1001/jama.2014.3201

3. Pulgaron ER, Delamater AM: Obesity and type 2 diabetes in children: epidemiology and treatment. Curr Diab Rep 2014; 14: 508-529. doi:10.1007/s11892-014-0508-y

4. Klingensmith GJ, Connor CG, Ruedy KJ, Beck RW, Kollman C, Haro H, et al., for the Pediatric Diabetes Consortium: Presentation of youth with type 2 diabetes in the Pediatric Diabetes Consortium. Pediatric Diabetes 2016; 17: 266-273. doi:10.1111/pedi.12281

5. Narasimhan S, Weinstock RS: Youth-onset type 2 diabetes mellitus: lessons learned from the TODAY Study. Mayo Clin Proc 2014; 89: 806-816. doi:10.1016/j.mayocp.2014.01.009

6. Alkorta-Aranburu, G, Carmody D, Chenga YW, Nelakuditia V, Maa L, Jazzmyne T, et al.: Phenotypic heterogeneity in monogenic diabetes: The clinical and diagnostic utility of a gene panel-based nextgeneration sequencing approach. Mol Genet Metab 2014; 113: 315-320. doi:10.1016/j.ymgme.2014.09.007

7. Prokai A, Fekete A, Kis E, Reusz GS, Sallay P, Korner A, et al.: Post-transplant diabetes mellitus in children following renal transplantation. Pediatr Transplantation 2008; 12: 643-649. doi:10.1111/j.1399-3046.2007.00862.x

8. Davidson J., Wilkinson A: New-onset diabetes after transplantation 2003 international consensus guidelines: An endocrinologist's view. Diabetes Care 2004; 27: 805-812. doi:10.2337/diacare.27.3.805

9. Shabir S, Jham S, Harper L, Ball S, Borrows R, Sharif A: Validity of glycated haemoglobin to diagnose new onset diabetes after transplantation. Transpl Int 2013; 26:315-321. doi:10.1111/tri.12042

10. Sharif A, Hecking M, De Vries AP, Porrini E, Hornum M, Rasoul-Rockenschaub $S$, et al.: Proceedings from an international consensus meeting on post transplantation diabetes mellitus: Recommendations and future directions. Am J Transplant 2015; 14: 1992-2000. doi:10.1111/ajt.12850

11. Luan FL, Steffick DE, 0jo A0: New-onset diabetes mellitus in kidney transplant recipients discharged on steroid-free immunosuppression. Transplantation 2011; 91:334-341. doi:10.1097/TP.0b013e318203c25f

12. Rana M, Munns CF, Selvadurai H, Donaghue KC, Craig ME: Cystic fibrosisrelated diabetes in children - gaps in the evidence? Nature Reviews Endocrinology 2010; 6: 371-378. doi:10.1038/nrendo.2010.85

13. Hameed S, Jaffé $A$, Verge CF: Advances in the detection and management of cystic fibrosis related diabetes. Curr Opin Pediatr 2015; 27: 525-533. doi:10.1097/MOP.0000000000000251

14. American Diabetes Association. Standards of medical care in diabetes -2013 . Diabetes Care 2013; 36(Suppl.1): S11-S66. doi:10.2337/dc13-S011

15. American Diabetes Association. Standards of medical care in diabetes 2016. 11. Children and Adolescents. Diabetes Care 2016; 39(Supplement 1): S86-S93. doi:10.2337/dc16-S014

16. Porta M, Sjoelie A-K, Chaturvedi N, Stevens L, Rottiers R, Veglio M, et al. and the EURODIAB Prospective Complications Study Group: Risk factors for progression to proliferative diabetic retinopathy in the EURODIAB Prospective Complications Study. Diabetologia 2001; 44: 2203-2209. doi:10.1007/s001250100030 
17. Flechtner I, Vaxillaire M, Cavé H, Scharfmann R, Froguel P, Polak M: Neonatal hyperglycaemia and abnormal development of the pancreas. Best Pract Res Clin Endocrinol Metab 2008; 22:17-40. doi:10.1016/j.beem.2007.08.003

18. Polak M, Cavé H: Neonatal diabetes mellitus: a disease linked to multiple mechanisms. Orphanet J Rare Dis 2007; 2: 12. doi:10.1186/1750-1172-2-12

19. Rubio-Cabezas O, Díaz González F, Aragonés A, Argente J, Campos-Barros A: Permanent neonatal diabetes caused by a homozygous nonsense mutation in the glucokinase gene. Pediatr Diabetes 2008; 9: 245-249. doi:10.1111/j.1399-5448.2007.00361.x

20. Støy J, Edghill EL, Flanagan SE, Ye H, Paz VP, Pluzhnikov A: Neonatal Diabetes International Collaborative Group: Insulin gene mutations as a cause of permanent neonatal diabetes. Proc Natl Acad Sci USA 2007; 104: 15040-15 044. doi:10.1073/pnas.0707291104

21. Gyurus EK, Patterson C, Soltesz G, Hungarian Childhood Diabetes Epidemiology Group: Twenty-one years of prospective incidence of childhood type 1 diabetes in Hungary--the rising trend continues (or peaks and highlands?) Pediatric Diabetes 2012; 13: 21-25. doi:10.1111/j.1399-5448.2011.00826.x

22. Lin A, Northam EA, Rankins D, Werther GA, Cameron FJ. Neuropsychological profiles of young people with type 1 diabetes $12 \mathrm{yr}$ after disease onset. Pediatr Diabetes 2010; 11: 235-243. doi:10.1111/j.1399-5448.2009.00588.x

23. Daneman D, Frank M, Perlman K, Wittenberg J: The infant and toddler with diabetes: Challenges of diagnosis and management. Paediatr Child Health 1999; 4: 57-63.

24. Tsalikian E, Fox L, Weinzimer S, Buckingham B, White NH, Beck B, et al. and the Diabetes Research in Children Network (DirecNet) Study Group: Feasibility of prolonged continuous glucose monitoring in toddlers with type 1 diabetes. Pediatr Diabetes 2012; 13: 301-307. doi:10.1111/j.1399-5448.2011.00837.x
25. Weissberg-Benchell J, Glasgow AM, Tynan WD, Wirtz P, Turek J, Ward J: Adolescent diabetes management and mismanagement. Diabetes Care 1995; 18: $77-82$. doi:10.2337/diacare.18.1.77

26. Cameron FJ, Amin R, de Beaufort C, Codner E, Acerini CL: ISPAD Clinical Practice Consensus Guidelines 2014. Diabetes in adolescence. International Society for Pediatric and Adolescent Diabetes. Pediatr Diabetes 2014; 15 Suppl 20: 245-256. do: 10.1111/pedi.12169

27. Goebel-Fabbri, Ann E: Disturbed eating behaviors and eating disorders in type 1 diabetes: clinical significance and treatment recommendations. Current Diabetes Reports 2009; 9: 133-139. doi:10.1007/s11892-009-0023-8

28. Bove D, Bove RM, Caccavale S, Bravaccio C, Marino M, La Montagna M: Adolescence, imperceptible boundary between normality and pathology: a literature review. Minerva Pediatr 2016; 68: 148-151.

29. White M, O'Connell MA, Cameron FJ: Transition to adult endocrine services: What is achievable? The diabetes perspective. Best Pract Res Clin Endocrinol Metab 2015; 29: 497-504. doi:10.1016/j.beem.2015.03.004

Közlésre érkezett: 2017. január 9.

Közlésre elfogadva: 2017. február 16.

A szerzö levelezési címe:

\section{Dr. Körner Anna}

Semmelweis Egyetem, I. Gyermekklinika

1083 Budapest, Bókay János u. 53-54.

E-mail: korner.anna@med.semmelweis-univ.hu 